\title{
Treatment of the Negative Symptoms of Schizophrenia with Verapamil
}

\author{
William A. Price, MD \\ Northeastern Ohio University College of Medicine \\ Dawn Heil \\ Northeastern Ohio University College of Medicine
}

Follow this and additional works at: https://jdc.jefferson.edu/jeffjpsychiatry

Part of the Psychiatry Commons

Let us know how access to this document benefits you

\section{Recommended Citation}

Price, MD, William A. and Heil, Dawn (1987) "Treatment of the Negative Symptoms of Schizophrenia with Verapamil," Jefferson Journal of Psychiatry. Vol. 5 : Iss. 1 , Article 9.

DOI: https://doi.org/10.29046/JJP.005.1.007

Available at: https://jdc.jefferson.edu/jeffjpsychiatry/vol5/iss $1 / 9$

This Article is brought to you for free and open access by the Jefferson Digital Commons. The Jefferson Digital Commons is a service of Thomas Jefferson University's Center for Teaching and Learning (CTL). The Commons is a showcase for Jefferson books and journals, peer-reviewed scholarly publications, unique historical collections from the University archives, and teaching tools. The Jefferson Digital Commons allows researchers and interested readers anywhere in the world to learn about and keep up to date with Jefferson scholarship. This article has been accepted for inclusion in Jefferson Journal of Psychiatry by an authorized administrator of the Jefferson Digital Commons. For more information, please contact: JeffersonDigitalCommons@jefferson.edu. 


\title{
Treatment of the Negative Symptoms of Schizophrenia with Verapamil
}

\author{
William A. Price, M.D. \\ Dawn Heil
}

\section{INTRODUCTION}

The illness of schizophrenia, as it is understood today, appears to consist of a heterogeneous group of disorders which share several common features, such as partial response to medications, poor long-term prognosis, and the presence of psychotic symptoms. These psychotic symptoms have been arbitrarily divided into two subgroups, positive and negative, in an attempt to better understand this disease process $(1,2)$. The positive symptoms, such as delusions and hallucinations, generally have an acute onset with frequent exacerbations and remissions and a favorable long-term prognosis and response to medications. The negative symptoms, which include affective blunting, social withdrawal, apathy, and anhedonia, tend to be chronic and typically fail to respond satisfactorily to standard neuroleptics (3). This fact has been illustrated in some schizophrenic patients by the retention of negative symptoms even after treatment and subsequent reduction of their positive symptoms. Researchers have concluded that the negative symptoms are more refractory than their positive counterparts based upon this frequently observed phenomenon (4).

This resistance has led to a search for agents more effective than the standard neuroleptics in relieving the emotional withdrawal, social isolation, and apathy of this "deficit" state. Research which utilizes such medications as L-dopa, sulpiride, and alprazolam for the treatment of these negative symptoms is currently underway (5). Gould and co-workers have found that members of the diphenylbutylpiperidine group of neuroleptics, such as pimozide, seem to be uniquely suited for the treatment of negative schizophrenic symptoms. These neuroleptics are structurally similar to verapamil-like drugs and have strong calcium blocking effects within the central nervous system (6). It is this unique effect upon calcium channels that is thought to be responsible for their efficacy in relieving the negative symptoms. Lithium carbonate, which also shares similarities to verapamil in that it alters calcium metabolism, blocks depolarization, and competes with calcium ions within the neuromuscular cells, has been useful in treating the negative symptoms of schizophrenia as well (7). Verapamil itself has been used successfully as a replacement for lithium carbonate in the

Dr. Price is chief resident in psychiatry, and an associate clinical instructor at Northeastern Ohio Universities College of Medicine. Ms. Heil is a third-year medical student at the same institution. 
treatment of acute mania $(8,9)$. It has also been used in preliminary studies to treat acute exacerbations of schizophrenia (10), but its usefulness in treating the negative symptoms of schizophrenia has yet to be explored. We report a case of a schizophrenic patient with prominent negative symptoms, previously resistant to treatment with the standard neuroleptics, that responded to verapamil.

\section{CASE REPORT}

The patient, a 36-year-old white male, was first seen because of his bizarre behavior and persistent auditory hallucinations. The patient was living in a group home at the time, and had been refusing to leave his bedroom closet because the voices in his head told him to stay in the closet. Overall, he was socially withdrawn and noncommunicative for most of the time. He felt anergic and found it difficult to get involved in the activities at the group home. His affect was flat with little variation. He denied feeling depressed and did not exhibit any disorder of his sleep or appetite. He first started having psychiatric problems at the age of 18 , when he was hospitalized for psychotic behavior. Since then he had had four other hospitalizations and had been on various neuroleptics, as well as short trials of lithium carbonate, oxazepam, and amitriptyline. At the present time, he was receiving thiothixene $40 \mathrm{mg} /$ day and trihexyphenidyl hydrochloride $2 \mathrm{mg}$ twice daily. For the most part, his hallucinations, delusions, and other positive symptoms responded well to medications, however, he had always been withdrawn, lacked the motivation to do things, and showed very little emotion at all.

Because of his partial response to neuroleptics in the past, it was decided that the patient be included in an ongoing research project that was investigating the use of verapamil, a calcium channel blocker, to treat the negative symptoms of schizophrenia. The patient was told that he would receive either verapamil, haloperidol, or placebo during the course of the study, and could withdraw at any time and continue to receive treatment. He signed informed consent forms at this time.

A complete physical examination as well as an electrocardiogram, an electroencephalogram, and routine laboratory tests such as complete blood count with differential, serum electrolytes, glucose, RPR, and liver and thyroid functions were all normal. The patient was initially started on haloperidol and the dose was gradually increased to $20 \mathrm{mg}$ /day after two weeks. At this time he stated that the auditory hallucinations had become less bothersome and he no longer responded to their commands. He continued, however, to be socially withdrawn and anergic, exhibiting marked anhedonia and blunting of affect. After six weeks of treatment with haloperidol, $30 \mathrm{mg} /$ day, he showed no further improvement. Placebo was started at this time, but after four weeks he was once again responding to his auditory hallucinations. The placebo was discontinued and verapamil was started at a dose of $80 \mathrm{mg}$ twice daily. The verapamil was gradually increased to $320 \mathrm{mg} /$ day by the second week. Upon evaluation, the 
patient reported an absence of auditory hallucinations and he seemed somewhat brighter and more talkative. Over the next four weeks he was noted to be more active on the unit and he exhibited a greater range of affect. In fact, at one point he was found playing a joke on several staff members. The patient tolerated the haloperidol, placebo, and verapamil well, noting only some initial sedation with the haloperidol and dizziness with the verapamil. These side effects passed quickly, and weekly vital signs, as well as bi-monthly electrocardiograms, were all unremarkable. The patient was discharged on verapamil $80 \mathrm{mg}$ four times daily, and he has continued to do well for the last six months.

\section{CONCLUSION}

Although this is only a single case report, the evidence suggests that verapamil can be effective in the treatment of schizophrenia. More specifically, verapamil seemed to be especially useful in reducing this patient's negative symptoms, which in the past had been resistant to treatment with the standard neuroleptics. Single case reports need to be weighed accordingly, but one should be aware that single case reports in the past, such as those involving alprazolam or L-dopa in the treatment of schizophrenia $(11,12)$, have proven to be the gateway for further investigation and success in the management and improvement of negative schizophrenic symptoms. The results of this case at least suggest the need for further research on the use of verapamil and other calcium channel blockers to treat the negative symptoms of schizophrenia.

\section{REFERENCES}

1. Jackson JH: Selected Writings. London, Hodder and Stoughton, 1931

2. Crow TJ: Molecular pathology of schizophrenia: more than one disease process? $\mathrm{Br}$ Med J 280:66-68, 1980

3. Andreasen NC: Positive vs. negative schizophrenia: a critical evaluation. Schizophrenia Bull 11:380-389, 1985

4. Johnstone EC, Crow TJ, Frith CD, et al: Mechanism of the antipsychotic effect in the treatment of acute schizophrenia. Lancet 1:848-851, 1978

5. Carpenter WT, Heinrichs DW, Alphs LD: Treatment of negative symptoms. Schizophrenia Bull 11:440-452, 1985

6. Gould RJ, Murphy KM, Reynolds IJ, et al: Antischizophrenic drugs of the diphenylbutylpiperidine type act as calcium channel antagonists. Proc Natl Acad Sciences 80:5122-5125, 1983

7. Donaldson SR, Gelenberg AJ, Baldessarini RJ: Treatment of schizophrenia: a progress report. Schizophrenia Bull 9:504-527, 1983

8. Giannini AJ, Houser WL, Loiselle RH, et al: Antimanic effects of verapamil. Am J Psychiatry 141:1602-1603, 1984

9. Giannini AJ, Loiselle RH, Price WA, et al: Comparison of antimanic efficacy of clonidine and verapamil. J Clin Pharmacol 25:307-308, 1985 
10. Price WA, Giannini AJ, Loiselle RH: Verapamil in the treatment of schizophrenia. $J$ Clin Pharmacol 29:461, 1985

11. Wolkowitz OM, Pickar D, Doran AR, et al: Combination alprazolam-neuroleptic treatment of the positive and negative symptoms of schizophrenia. Am J Psychiatry 143:85-87, 1986

12. Kay SR, Opler LA: L-dopa in the treatment of negative schizophrenic symptoms: a single-subject experimental study. Int J Psychiatry Med 15:293-298, 1985-1986 